\title{
Alveolar sampling and fast kinetics of tetrachloroethene in man. II Fast kinetics
}

\author{
J J G OPDAM, J F J SMOLDERS
}

From the Coronel Laboratory, Faculty of Medicine, University of Amsterdam, 1105 AZ Amsterdam, the Netherlands

ABSTRACT Fast kinetic phenomena were studied in human subjects exposed to tetrachloroethen禺 (perchloroethylene, PER). The duration of exposure ranged from one to 60 minutes and the concents tration of PER in inhaled air ranged from 0.02 to $0.40 \mathrm{mmol} / \mathrm{m}^{3}$. The PER concentration in mixed venous blood (pulmonary artery) was estimated by alveolar concentration $\left(\mathbf{C}_{\text {Alv }}\right)$ measured after residence time of $10 \mathrm{~s}$. During exposure, stoppage of intake (breath holding up to $50 \mathrm{~s}$ ) caused $\$$ decrease of $\mathrm{C}_{\mathrm{Alv}}$ down to about $60 \%$ of the $\mathrm{C}_{\mathrm{Alv}}$ at a residence time of $10 \mathrm{~s}$. At the end of exposure, stoppage of intake (breathing fresh air) caused a decrease of $C_{A l v}$ with $t_{\frac{1}{2}}=15-25 \mathrm{~s}$; after two tᄒ four minutes, the decrease slowed down abruptly and the concentration remained more or les? constant for about one to three minutes. After this stationary level, the decrease of $\mathrm{C}_{\mathrm{Alv}}$ continue but at a slower rate. During and after exposure, the decrease of $\mathrm{C}_{\mathrm{Alv}}$ seems to be caused by large differences in the circulation times of blood flowing through rapid, well perfused tissues and slowero well perfused tissues which may explain the stationary level. From this point of view, the vessel rich group in a compartment model must be split up in order to predict tissue and organ concentrations during peak environmental concentrations.

Human biological monitoring is a valuable tool with which to estimate quantitatively exposure to toxic agents. The exposure level is usually determined as a time weighted average; this means that peak concentrations are seldom taken into account.

Rapid changes in environmental concentrations may result in rapid and large differences in the concentration in organs or tissues. The distribution of a toxic agent in the human body is often described by compartment models in which the blood circulation times are set at zero. In the models the concentration of the agent in several groups of tissues and organs is often calculated by means of the estimated tissue volume, blood perfusion, and the tissue blood partition coefficient. ${ }^{1}$

A more detailed modelling may be useful in predicting the magnitude and duration of differences in concentration in organs and tissues during and after peak concentration.

Mapleson suggested that for a few minutes after a change of the inhaled concentration the various circulation times of blood through the tissues and organs might play an important part in the time course of the concentration in mixed venous blood. ${ }^{2}$ The concen-

Accepted 2 April 1986

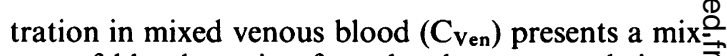
ture of blood coming from local organs and tissue with local perfusion, partition coefficients, and circu lation times.

Frequent sampling of mixed venous blood after a. change in the inhaled concentration is almost imposo sible but the sampling of alveolar air provides a valiథ estimate of the mixed venous concentration and makes it possible instantaneously to follow fast. changes in $\mathrm{C}_{\text {Ven }}$. From exposure tests with teto rachloroethene (perchloroethylene, PER), we have shown that alveolar sampling in the postexposure period had much less variability than durings exposure. $^{3}$

The purpose of the present study was to assess fast kinetic phenomena in the early postexposure timer after the abrupt cessation of respiratory intake of PER.

\section{Methods}

PROCEDURE

Six volunteers ( 3 men, 3 women) were exposed severato times at rest to constant concentrations of PER in airo

The exposures, apparatus, sampling, sampling errors, and analysis have been described elsewhere. 
In that paper the alveolar sampling technique was studied by taking samples after several episodes of breath holding. A distinction was made between breath holding time and residence time $\left(\mathrm{t}^{*}\right)$; the latter was defined as the time interval between the beginning of inhalation and the end of the next exhalation. All samples taken after a certain breath holding time are expressed with their corresponding residence times. At a respiratory frequency of $12 / 0$, a zero breath holding time corresponds to $\mathrm{t}^{*} \simeq 5 \mathrm{~s}$.

In the early postexposure period (0-30 min) an alveolar sample was sometimes taken from each second or third exhalation after a 5,10 , or 20 s residence time. Extra attention was also paid to long breath holding - that is, $\mathrm{t}^{*}>10 \mathrm{~s}$-during exposure.

\section{Results}

\section{COURSE OF ALVEOLAR CONCENTRATION}

Figure 1 shows an overall view of the course of the alveolar concentration $\left(\mathrm{C}_{\mathrm{Alv}}\right)$. It has been shown that during exposure $\mathrm{C}_{\mathrm{Alv}}$ decreases with increasing resi- dence time. ${ }^{3}$ At $t^{*} \leqslant 10 \mathrm{~s}$, the decrease of $\mathrm{C}_{\text {Alv }}$ may be described by an exponential curve; at about $\mathrm{t}^{*}=10 \mathrm{~s}$, the curve tends to stabilise at about $80 \%$ of $\mathrm{C}_{\mathrm{Alv}}\left(\mathrm{t}^{*}=\right.$ $5 \mathrm{~s})$. At $\mathrm{t}^{*}>10 \mathrm{~s}$, however, $\mathrm{C}_{\mathrm{Alv}}$ decreases more rapidly again; this decrease continues up to at least $\mathrm{t}^{*}=$ $55 \mathrm{~s}$, and the alveolar concentration is about $40 \%$ of the alveolar value at $\mathrm{t}^{*}=5 \mathrm{~s}$.

Immediately after the end of exposure, $C_{A l v}$ decreases rapidly. After a short period $\left(t_{2}-t_{1}\right)$ of two to four minutes, the rate of decrease slows down abruptly and drops almost to zero for a short period $\left(t_{3}-t_{2}\right)$.

In the postexposure period at $t-t_{1}>0.5 \mathrm{~min}$, the $\left(t^{*}=5 \mathrm{~s}\right)$ values are lower than the $\left(t^{*}=10 \mathrm{~s}\right)$ values and they both decrease in a constant ratio of 0.93 (table 1).

In the first 3.5 minutes of the postexposure period, the $\left(\mathrm{t}^{*}=10 \mathrm{~s}\right)$ values are lower than the $\left(\mathrm{t}^{*}=20 \mathrm{~s}\right)$ values; both decrease in a ratio of 0.90 . During the next 30 minutes, this ratio becomes 0.96 whereas after four hours the $\left(\mathrm{t}^{*}=10 \mathrm{~s}\right)$ and $\left(\mathrm{t}^{*}=20 \mathrm{~s}\right)$ values are no longer distinguishable (table 1$)$.

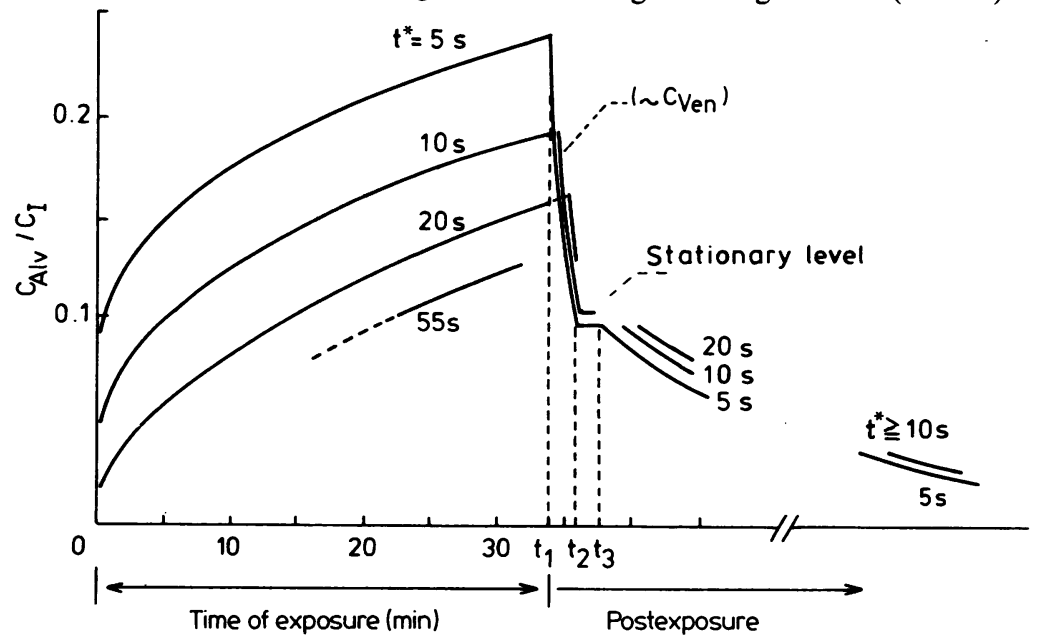

Fig 1 Overall view of alveolar concentration curves relative to inhaled concentration $\left(C_{1}\right)$ of $P E R$ at different residence times $\left(t^{*}\right)$. In postexposure period lines are drawn schematically. At $t>240$ min there was no difference between sampling with $t^{*}=10 \mathrm{~s}$ and $t^{*} \geqslant 20 \mathrm{~s}$.

Table 1 Difference in alveolar concentration of tetrachloroethene (PER) at different residence times in the postexposure period*

\begin{tabular}{|c|c|c|c|c|}
\hline \multirow[b]{2}{*}{ Postexposure time (min) } & \multirow{2}{*}{$\frac{C_{A l v}\left(t^{*}=5 \mathrm{~s}\right)}{C_{A l v}\left(t^{*}=10 \mathrm{~s}\right)}$} & \multirow{2}{*}{$\frac{C_{A l v}\left(t^{*}=10 \mathrm{~s}\right)}{C_{A t v}\left(t^{*}=20 \mathrm{~s}\right)}$} & \multicolumn{2}{|l|}{ No of } \\
\hline & & & Data & Experiments \\
\hline $\begin{array}{l}0 \cdot 5-4000 \\
1 \cdot 5-3 \cdot 5 t \\
4-35 t \\
4-1500\end{array}$ & $0.93 \pm 0.04$ & $\begin{array}{l}0.90 \pm 0.02 \\
0.96 \pm 0.02 \\
0.98 \pm 0.02\end{array}$ & $\begin{array}{r}14 \\
4 \\
9 \\
15\end{array}$ & $\begin{array}{l}5 \\
4 \\
6 \\
6\end{array}$ \\
\hline
\end{tabular}

*Values expressed as ratios ( $\overline{\mathrm{x}} \pm \mathrm{SD})$.

†Short postexposure period before stationary level.

†Postexposure period beyond stationary level. 

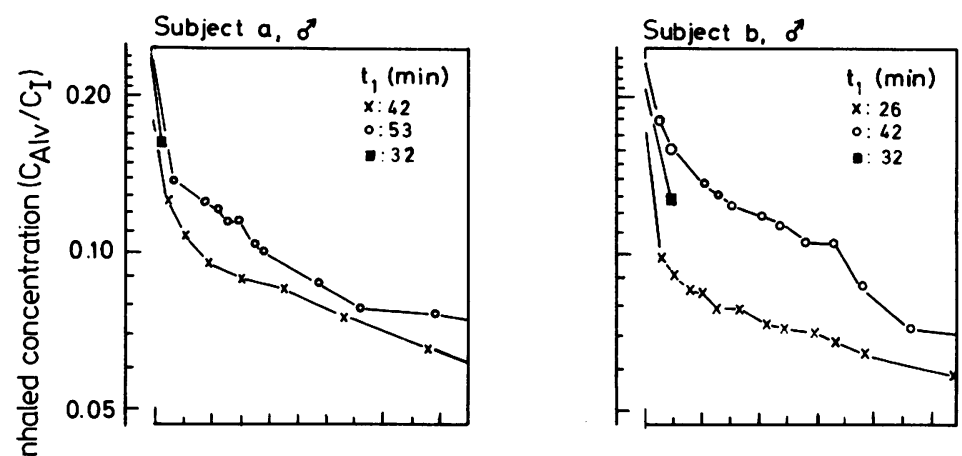

Subject d. $q$

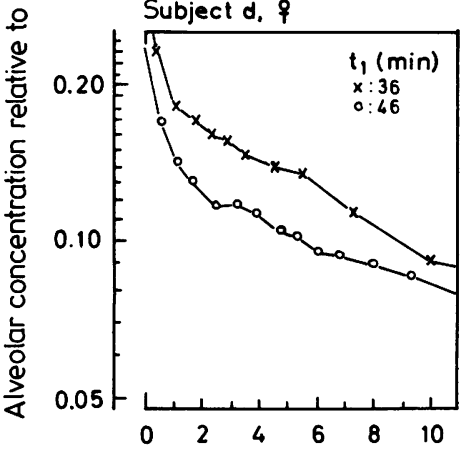

Subject e, 9

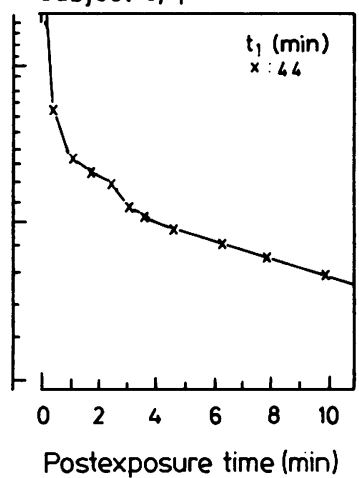

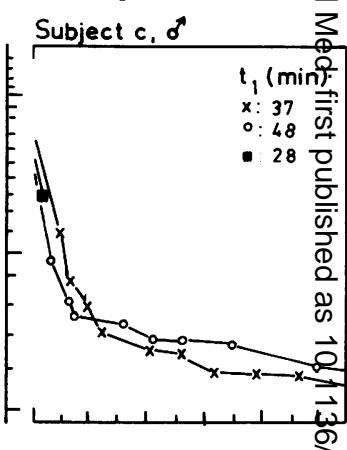

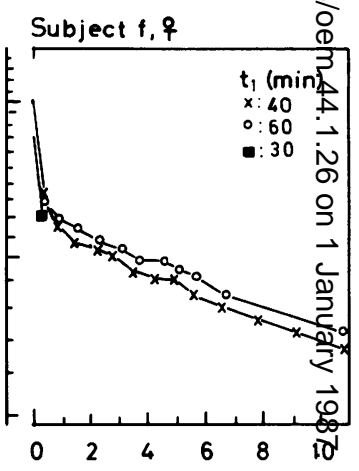

\section{๖}

Fig 2 Semilog plots of $C_{\mathrm{Alv}} / C_{\mathrm{I}}$ in early postexposure period for six subjects. Different experiments with same subject are represented by symbols $O, x$, and $\square$; symbol $\square$ was measured from first exhalation after a short period of breath holding immediately after exposure at $t_{1} ; t_{1}$ is duration of exposure. Extrapolation to zero postexposure time points in direction of $C_{\mathrm{A} 1} t_{\mathbb{D}}^{*}$
$\left(t^{*}=10 \mathrm{~s}\right)$ at $t_{1}$.

STATIONARY LEVEL

Figure 2 shows semilog plots of the time courses of $\mathrm{C}_{\mathrm{Alv}}\left(\mathrm{t}^{*}=10 \mathrm{~s}\right)$ in the early postexposure period for six subjects. In most experiments a fast rate of decrease is followed abruptly by a much smaller rate for a short period. During this short period, $\mathrm{C}_{\mathrm{Alv}}$ sometimes tends to remain at a constant level: a stationary level. This short period ranged from about one (subjects a, e) to three minutes.

Beyond the stationary level the rate of decrease increases again and yields a smooth exponential decrease. Two exponential curve fitting procedures were carried out with the experimental data beyond the stationary level up to 60 minutes after exposure (appendix 2, eq 2); the curve could be fitted with a weighted residual error of only $2.5 \%$ (appendix 2 , eq 3 ). Because of the stationary level it is difficult to fit a smooth multiexponential decrease for the whole postexposure period. The results in fig 2 do not, in general show a clear constant concentration level. For a short period, however, the concentrations seem more or less constant (a level); beyond this level the rate of $\mathrm{C}_{\mathrm{Alv}}$ decrease increases again. Because of the small weighted residual error around the fitted curve with the data beyond the stationary level, this level and the increase of the rate of $\mathrm{C}_{\mathrm{Alv}}$ decrease cannot be expla $\overrightarrow{\bar{\delta}}$ ined by random or systematical errors.

There was usually some intraindividual variabilit in the course of $\mathrm{C}_{\mathrm{Alv}}$ during exposure between the experiments. In figure 2 this becomes obvious fron the $\mathrm{C}_{\mathrm{Alv}}$ value at zero post exposure time (subjects c, and d). The postexposure courses of $\mathrm{C}_{\mathrm{Alv}}$ of subject $\mathrm{d}$ may be explained by hyperventilation during the $3 \overline{9}$. minute exposure (symbol $\times$ ). Its total uptakg exceeded the total uptake during the 48 minute exposure (symbol $\bigcirc$ ).

Figure 3 presents both the relative alveolar concen? tration $\left(\mathrm{C}_{\mathrm{Alv}}\left(\mathrm{t}^{*}=10 \mathrm{~s}\right)\right)$ at the end of exposure an the concentration of the stationary level $\left(\mathrm{C}_{\mathrm{SL}}\right)$ as func. tions of the duration of exposure in 17 experiments of subject a.

FAST POSTEXPOSURE DECREASE OF ALVEOLAR CONCENTRATION

The actual time of exposure ends when the volume of the last inhalation equilibrates with $\mathrm{C}_{\text {Ven }}$ - that is, the net gas transfer into blood is zero. At this time $\left(t_{1}\right)$ the alveolar concentration has the value of $\mathrm{C}_{\mathrm{Alv}}\left(\mathrm{t}^{*}\right.$ $10 \mathrm{~s}$ ) and decreases at $\mathrm{t}>\mathrm{t}_{1}$ because the uptake of PER has stopped. 


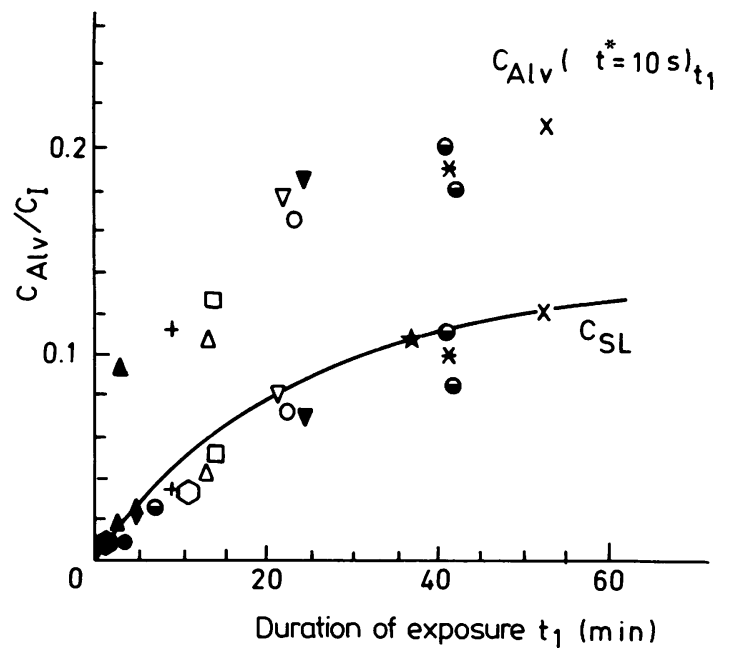

Fig 3 Relative alveolar concentration of PER at end of exposure $\left(C_{\mathrm{Alv}}\left(t^{*}=10 \mathrm{~s}\right) t_{1}\right.$ : upper symbols $)$ and corresponding relative stationary level concentration in experiments on subject a; each experiment has same symbols. Drawn line was calculated by means of equation 1 (appendix 2) with estimated two coefficients and two exponents which were obtained by two exponential curve fitting (eq 2, appendix 2) with measured concentrations beyond stationary level $\left(t>t_{3}\right)$ of one experiment (symbol $\left.\ominus\right)$.

The experiments showed a multiexponential decrease of $\mathrm{C}_{\mathrm{Alv}}\left(\mathrm{t}^{*}=10 \mathrm{~s}\right)$, which is representative of mixed venous blood; it starts with $\mathrm{C}_{\text {Alv }}\left(\mathrm{t}^{*}=10 \mathrm{~s}\right)$ at $t_{1}$ and approaches the stationary level $C_{S L}$ at $t_{2}$. The subjects showed for $t_{1}<t<t_{2}$ an intra/intervariability in the rate of $C_{\text {Alv }}$ decrease with $t_{\frac{1}{2}}=$ $15-25 \mathrm{~s}$ at $t_{1}$, whereas after about $25 \mathrm{~s}$ the $t_{\frac{1}{2}}$ ranged from 20 to $50 \mathrm{~s}$.

The $t_{\frac{1}{2}}$ is defined as the halftime of the $\mathrm{C}_{\mathrm{Alv}}$ decrease between $\mathrm{C}_{\mathrm{Alv}}\left(\mathrm{t}^{*}=10 \mathrm{~s}\right)$ at $\mathrm{t}_{1}$ and $\mathrm{C}_{\mathrm{SL}}$ at $\mathrm{t}_{2}$. The half times at the end of exposure were obtained from a semilog plot of the data. These data were obtained from frequent sampling - for example from each second or third exhalation - and fitted by hand.

No relation was observed between duration of exposure $\left(t_{1}\right)$ and half time $\left(t_{\frac{1}{2}}\right)$. In some experiments immediately after exposure the subject did not inhale fresh air but held his breath for 15-60 s. When compared with normal fresh air breathing, this breath holding does not substantially effect the $t_{\frac{1}{2}}$ value (fig 2, symbol $\mathbf{\square}$ ).

\section{Discussion}

FAST CAlv-DECREASE AND THE STATIONARY LEVEL

$\mathrm{C}_{\mathrm{Alv}}$ equilibrates with $\mathrm{C}_{\mathrm{Ven}}$ at $\mathrm{t}^{*}=10 \mathrm{~s}$; indicates that at $\mathrm{t}^{*}>10 \mathrm{~s}, \mathrm{C}_{\mathrm{Alv}}$ represents $\mathrm{C}_{\mathrm{Ven} .}{ }^{3}$ Alveolar air sam- pling was carried out discontinuously but frequent sampling with $\mathrm{t}^{*}=10 \mathrm{~s}$ gives the rate of change in the mixed venous concentration. At the end of exposure, $\mathrm{C}_{\text {Alv }}\left(\mathrm{t}^{*}=10 \mathrm{~s}\right)$ decreased rapidly until it reached a stationary level (fig 1). Breath holding at the end of exposure did not substantially delay the decrease. Thus the decrease of $\mathrm{C}_{\mathrm{Alv}}$ is not caused only by the respiratory excretion but mainly by a fast "internal" decrease in $\mathrm{C}_{\mathrm{Ven}}$. This $\mathrm{C}_{\mathrm{Ven}}$ is a composite of venous concentrations coming from rapid and slower perfused organs and tissues. Some explanations for the fast $\mathrm{C}_{\mathrm{Alv}}$ or $\mathrm{C}_{\mathrm{Ven}}$ decrease at $\mathrm{t}_{\mathbf{1}}$ or both, may be suggested: $(a)$ absorption of PER in the airways, $(b)$ absorption by lipid contents in the lung tissue, and (c) fast clearance of PER by organs and tissues. Absorption by the airways is unlikely as PER is almost insoluble in water. ${ }^{4}$

Significant lipid contents in lung tissue might continuously absorb PER from the alveolar air and blood in the capillary bed. In this way a significant contribution to the alveolar decrease is not likely because the rate of $\mathrm{C}_{\mathrm{Alv}}$ decrease does not depend on the duration of exposure and in the early postexposure period breath holding $\left(t^{*}>10 \mathrm{~s}\right)$ does cause an increase of $\mathrm{C}_{\mathrm{Alv}}$ (table 1 and fig 1 ).

The clearance of PER from the blood by unsaturated perfused organs and tissues may be significant; at $\mathrm{t}=30 \mathrm{~min}$, the alveolar retention still equals about $75 \%$ during normal breathing $\left(t^{*}=5 \mathrm{~s}\right)$ (fig 1). It is not likely that those perfused tissues (splanchnic tissue, muscles, and fat, for example) are capable of causing the fast $\mathrm{C}_{V_{\text {en }}}$ decrease at $\mathrm{t}_{1}$. The fast $C_{V_{e n}}$ decrease at $t_{1}$ implies that the local venous concentration coming from at least one organ, tissue, or shunt must decrease rapidly. Therefore, one has to consider the distribution of the blood. Table 2 shows the values for the distribution of blood for four compartments in a standard man. The total blood volume has been shared between compartments in the same proportions as the cardiac output which leads to the same (total) circulation tissue for all compartments. This distribution is often used in conventional compartment modelling in which the circulation times are set at zero. ${ }^{1}$ A more likely distribution is listed in table 3; the blood volume in each tissue in the vessel rich group (VRG) is based on estimated local blood flows and transit times. ${ }^{2}$ The remaining blood volume has been shared between the muscle group (MG) and fat group (FG) compartment in proportion to their flows. Simulation for PER was carried out with a four compartment model that was written for trichloroethene $^{1}$; in the present paper the model was used with zero metabolism because of the negligible metabolism of PER. Simulation during exposure for one hour for a standard man (table 2) showed that the partial presses in the muscle $\left(\mathbf{P}_{\mathrm{MG}}\right)$ and fat group $\left(\mathrm{P}_{\mathrm{FG}}\right)$ are 
about $35 \%$ and $0.7 \%$ of the solvent arterial pressure $\left(\mathrm{P}_{\mathrm{Art}}\right)$. This means that the local venous concentrations coming from both groups continue to increase during some postexposure period until $P_{M G}$ $=\mathbf{P}_{\mathrm{Art}}$ or $\mathbf{P}_{\mathbf{F G}}=\mathbf{P}_{\mathrm{Art}}$. In addition it is not expected that the contribution to $\mathrm{C}_{\mathrm{Ven}}$ from both groups would decrease within $40 \mathrm{~s}$ after stoppage of intake because of their circulation times which are $>40 \mathrm{s.}^{2}$ Even the local venous concentration coming from the splanchnic tissue does not decrease within its corresponding circulation time of about $55 \mathrm{~s}$ (table 3). Nevertheless, the splanchnic tissue belongs to the VRG and would be expected to have a much higher local venous partial pressure than $\mathbf{P}_{\mathbf{M G}}$ and $\mathbf{P}_{\mathbf{F G}}$ at time $t_{1}$. Therefore, splanchnic tissue probably also plays an important part in the course of $\mathrm{C}_{\mathrm{Ven}}$ in the early postexposure period because of its relative high contribution to $\mathrm{C}_{\text {Ven }}$.

Those tissues, organs, or shunts from which the local venous concentrations are able to react almost immediately at $t_{1}$ must have a short circulation time, however, and a rather small distribution volume.
WELL PERFUSED COMPARTMENT WITH A SHOR CIR CULATION TIME

Some questions may arise about the fast phenomen superimposed during exposure on the slower $\mathrm{C}_{\mathbf{S L}}$ cort? centration course (fig 3). The above discussion give good reasons to suppose the existence of rapidly pe를 fused organs, tissues, or shunts that have: $(a)$ a sho circulation time of $10-15 \mathrm{~s},(b)$ a rather small capacito for PER, and (c) an ability to raise substantially thos venous concentration coming from slower parts up to the estimated mixed venous concentration.

Mapleson has reviewed the data on transit time $\overrightarrow{\varepsilon_{0}}$ tissue volumes, and blood volumes for a standares $\operatorname{man}^{2}$ (table 3). The transit time is the flow time froro local artery to local vein; for an organ or tissue, ths time may be estimated by dividing the correspondin blood volume by the blood flow. The highway circulation time refers to the flow time from left ventricfer to local artery and from local vein to right atrium: the is estimated to be about $5.5 \mathrm{~s}$. The pulmonary circulation time is estimated to be $7.5 \mathrm{~s}$; this time is comb mon to circulations coming from all organs and tis

Table 2 Tissue and blood volumes, blood perfusions, and partition coefficients of PER for standard man at rest according to $\stackrel{\varrho}{\gtrless}$ several authors*

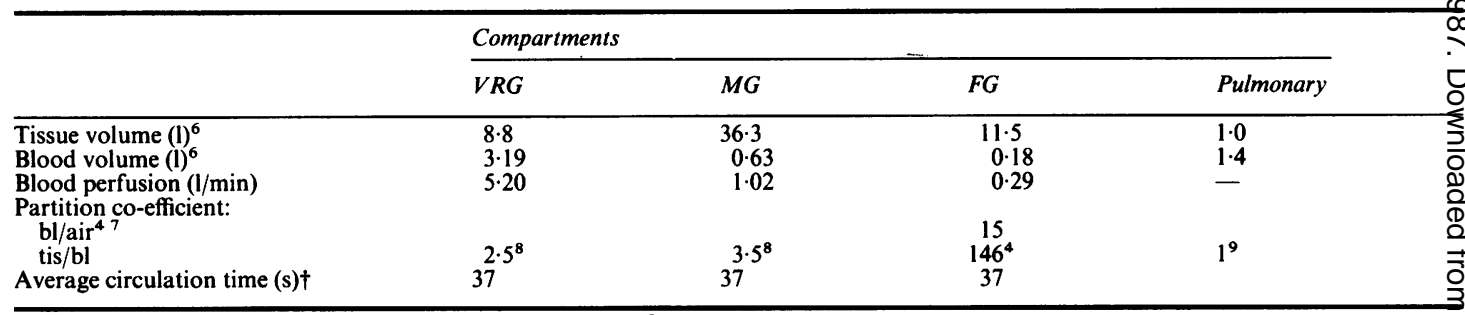

*Standard man: body weight $70 \mathrm{~kg}$, body surface area $1.8 \mathrm{~m}^{2}$, and eardiac output $6.51 / \mathrm{min}$.

$\dagger$ Average circulation time equals blood volume divided by blood flow.

Table 3 Preferred tissue volumes, blood volume, blood flows $(\dot{Q})$, transit and total circulation times for a standard man ${ }^{2 *}$

\begin{tabular}{|c|c|c|c|c|c|}
\hline & Volume (l) & Blood volume§ (l) & $\dot{Q}(l / \min )$ & Transit time $(s)$ & Total circ time $(s) \emptyset$ \\
\hline \multirow[b]{2}{*}{$\begin{array}{l}\text { Lung parenchymal tissue } \\
V R G \text { Ridneys } \\
\text { Kidrenals } \\
\text { Adreid } \\
\text { Thyroid } \\
\text { Heart } \\
\text { Brains } \\
\text { Other glands and organs } \\
\text { Splanchnic tissue }\end{array}$} & 0.5 & & & & \\
\hline & $\begin{array}{l}0 \cdot 28 \\
0.02 \\
0.02 \\
0 \cdot 28 \\
1.43 \\
0 \cdot 18 \\
3 \cdot 73\end{array}$ & $\begin{array}{l}0.052 \\
0.004 \\
0.004 \\
0.03 \\
0.11 \\
1.05\end{array}$ & $\begin{array}{l}1.25 \\
0 \cdot 10 \\
0 \cdot 10 \\
0 \cdot 24 \\
0 \cdot 79 \\
0.05 \\
1.53\end{array}$ & $\begin{array}{l}2 \cdot 5 \\
2 \cdot 5 \\
2 \cdot 5 \\
6 \cdot 5-11 \\
8 \cdot 5 \\
8 \cdot 5 \\
41\end{array}$ & $\begin{array}{l}15 \cdot 5 \\
15 \cdot 5 \\
15 \cdot 5 \\
19 \cdot 5-24 \\
21.5 \\
21.5 \\
54\end{array}$ \\
\hline \multirow{4}{*}{$\begin{array}{l}\text { Total } \\
\text { Average time } \dagger \\
\text { MG } \\
\text { Total } \\
\text { Average time } \dagger \\
\text { FG } \\
\text { Total } \\
\text { Average time } \dagger \\
\text { Peripheral shunt } \ddagger\end{array}$} & 5.94 & $2 \cdot 08 \|$ & 4.06 & 31 & 44 \\
\hline & $37 \cdot 4$ & $2 \cdot 17$ & $1 \cdot 13$ & 115 & 128 \\
\hline & $12 \cdot 8$ & 0.58 & 0.30 & & \\
\hline & - & 0.56 & & ${ }_{32 \cdot 5}^{115}$ & $\begin{array}{r}128 \\
40\end{array}$ \\
\hline \multicolumn{6}{|c|}{$\begin{array}{l}\text { *Standard man: } 70 \mathrm{~kg} \text {, aged } 30-39,1.85 \mathrm{~m}^{2} \text { body surface area. } \\
\text { tAverage circulation time equals blood volume divided by blood flow. } \\
\text { tIn this paper both fast and slow shunt are assumed to have } Q=0.52 \mathrm{l} / \mathrm{min} \text {. } \\
\text { \$Blood volume estimated as blood flow } \times \text { transit time. } \\
\text { |Including the blood volume }(0.83 \mathrm{l}) \text { in the pulmonary circulation and heart chambers. } \\
\text { 9Total circulation time equals sum of transit time, highway }(5.5 \mathrm{~s}) \text { and pulmonary time }(7.5 \mathrm{~s}) \text {. }\end{array}$} \\
\hline
\end{tabular}


sues. The total circulation time is the sum of transit time, highway circulation, and pulmonary circulation time.

Although the average circulation time for the visceral compartment (vessel rich, VRG) is estimated to be $44 \mathrm{~s}$, a blood flow of $1.45 \mathrm{l} / \mathrm{min}$ returns to the lungs within $15.5 \mathrm{~s}$; for a blood flow of $2.551 / \mathrm{min}$, the time is $21.5 \mathrm{~s}$ (table 3 ). Blood coming through the splanchnic tissue, however, returns after about $55 \mathrm{~s}$. In respect to circulation times, the visceral compartment may be split up into these subgroups: VRG la (kidney, adrenals, and thyroid, etc), VRG 1b (heart, brains, and other small glands and organs), and VRG 2 (splanchnic tissue).

The peripheral shunt in table 3 will probably also be a composite of several shunts. Arteriovenous anastamoses in the skin and muscles provide well known shunts. The average circulation time equals about $39 \mathrm{~s}$ but some shunts probably have much shorter times. The numerical values of bloodflows and circulation times of various shunts are uncertain, but the total peripheral shunt of table 3 can probably be split up into rapid and slow shunts; we assume both have equal blood flow $(\simeq 0.5 \mathrm{l} / \mathrm{min})$ with circulation times of $10 \mathrm{~s}$ and $60 \mathrm{~s}$ respectively.

Figure 4 presents a compartment model; in view of

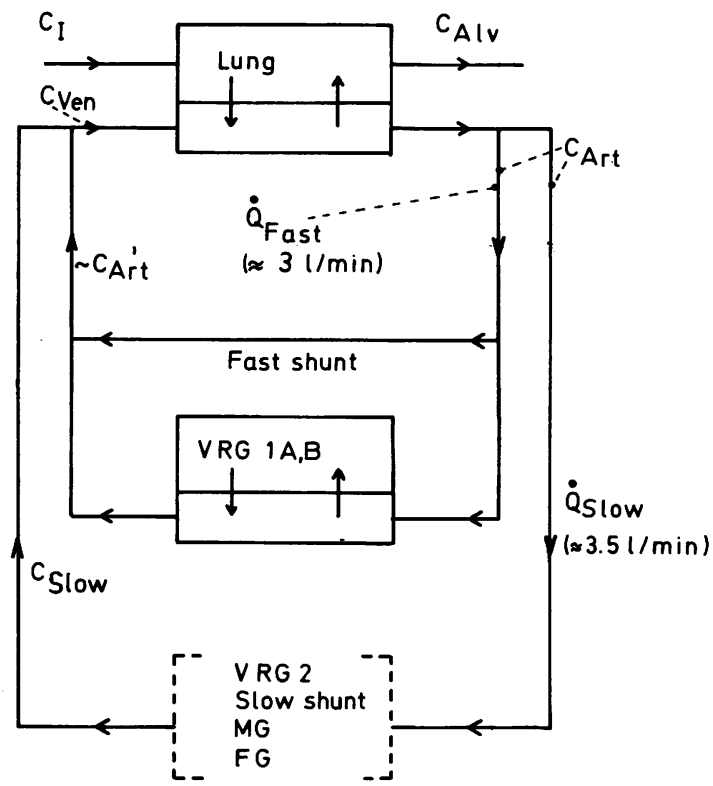

Fig 4 Compartment model based on physiological data of blood circulation times of organs and tissues which belong to vessel rich group (table 4). VRG is split into VRG 1 and VRG 2. Composition is assumed to be: VRG 1: kidney, adrenals, thyroid, heart, brains, other small glands, and organs; VRG 2: splanchnic tissue. Total arteriovenous shunt is split into a fast and a slow part. the circulation times the VRG has been split up and fast and slow shunts have been added.

With the exception of the brain, all tissues in the VRG 1 compartment have a small tissue volume, a small (tissue/blood) partition coefficient (table 2) and therefore a small capacity (distribution volume) to absorb PER. Shunts will have an even smaller capacity. These very rapidly perfused tissues and organs will equilibrate quickly with $\mathrm{C}_{\text {Art }}$ and their local venous blood will react almost immediately to changes in $\mathrm{C}_{\text {Art }}$.

The rise in the local venous concentration at a level $\mathrm{C}_{\mathrm{SL}}{ }^{*}\left(\simeq \mathrm{C}_{\mathrm{SL}}\right.$; fig 3$)$ up to the $\mathrm{C}_{\text {Ven }}$ value $\left(\mathrm{C}_{\mathrm{Alv}}\right.$ at $\left(\mathrm{t}^{*}=\right.$ $10 \mathrm{~s})$ may be plausibly explained. To put it simply, a composition of bloodflows with $\mathrm{C}_{\mathrm{SL}}{ }^{*}$ and $\mathrm{C}_{\mathrm{Art}}$ must yield $\mathrm{C}_{\mathrm{Ven}}$. During exposure, local venous blood coming from the shunt and VRG 1 tissues has a concentration almost equal to $C_{\text {Art }}$ (fig 4). Venous blood coming from slower VRG 2, MG, and FG compartments and slow shunt is mixed and results in a course of the concentration $\left(\mathrm{C}_{\text {Slow }}\right)$ which is assumed to be the same as the time course of the concentration at the stationary level $\left(\mathrm{C}_{\mathrm{SL}}{ }^{*}\right)$ (fig 3). Mixed venous blood may be regarded as a composite of the two mentioned venous blood flows: this yields a $\mathbf{C}_{\text {Ven }}$ value that is about $20 \%$ lower than the $C_{\text {Ven }}$ value $\left(t^{*}=10 \mathrm{~s}\right)(\mathrm{fig}$ 1).

Although this calculated $\mathrm{C}_{\mathrm{Ven}}$ value is rather low, it is shown that shunts and VRG 1 tissues can increase venous concentration considerably up to the mixed venous level measured at $\mathrm{t}^{*}=10 \mathrm{~s}$.

\section{FAST CVen DECREASE: A MONOEXPONENTIAL A PPROACH}

Simulations for PER with the four compartment model for a standard man (table 2) yielded a fast smooth decrease with a half time of $>0.5 \mathrm{~min}$ immediately after the end of exposure. Even the introduction of an artificially fast (highly perfused) small compartment does not simulate a stationary level. The estimated average circulation times of the three peripheral compartments appear about to be equal (table 2).

A monoexponential $\mathbf{C}_{\text {ven }}$ decrease between $\mathbf{C}_{\text {Ven }}$ $\left(t_{1}\right)$ and $C^{*}$ sL $\left(t_{2}\right)$ which is assumed to be caused only by internal PER redistribution, may be estimated by means of a mass balance equation which describes a fast system (fig 4). This fast system consists of VRG 1, fast shunt, and the corresponding blood volume including the blood in pulmonary circulation and heart chambers (table 3 ). The parenchymal lung tissue is excluded because its local venous blood is not supplied to the mixed venous blood but to the arterial blood (left atrium). The mass balance equation describes the fast PER transport into and out of the fast circulation system. During $\left(t_{2}-t_{1}\right) C_{\text {Slow }}$ is 
assumed to be of the same value as $C^{*}$ sL at $t_{2}$; this is justified by the slow change of $\mathrm{C}_{\text {Slow }}$ at $\mathrm{t}_{1}$ due to the slow change of the local venous concentrations coming from the slower perfused organs and tissues. The mass balance equation is:

$$
\mathrm{V}_{\text {Fast }} \mathrm{C}_{\text {Ven }}=\mathrm{C}_{\text {Slow }} \mathbf{Q}_{\text {slow }} \Delta \mathrm{t}-\mathrm{C}_{\text {Art }} \mathbf{Q}_{\text {Slow }} \Delta \mathrm{t}
$$

where $\mathrm{C}_{\mathrm{Art}}=\mathrm{C}_{\mathrm{Ven}}$, due to the assumed zero respiratory excretion and $\mathrm{C}_{\text {slow }} \simeq \mathrm{C}^{*} \mathrm{sL}$. The solution is:

$$
\begin{array}{r}
\mathrm{C}_{\text {Ven }}(\mathrm{t})=\mathrm{C}^{*}{ }_{\text {SL }}+\left(\mathrm{C}_{\text {Ven }}\left(\mathrm{t}_{1}\right)-\mathrm{C}^{*}{ }_{\text {SL }}\right) \\
\exp \left(\left(-\frac{\text { Q }_{\text {Slow }}}{\mathrm{V}_{\text {Fast }}}\right)\left(\mathrm{t}-\mathrm{t}_{1}\right)\right)
\end{array}
$$

$\mathrm{t}_{1} \leqslant \mathrm{t} \leqslant \mathrm{t}_{2}$

The distribution volume $\left(\mathrm{V}_{\text {Fast }}\right)$ is defind as the total volume of the fast system which is instantaneously in equilibrium with local venous concentration during rapid changes in $\mathrm{C}_{\text {Art }}$. Two extreme conditions are considered during the rapid $\mathrm{C}_{\text {Ven }}$ decrease: $(a)$ all VRG 1 tissues - for example, kidney and brain - are assumed to be completely in equilibrium with the local venous concentration as it leaves them; this yields $\mathrm{V}_{\text {Fast }}=6.71$, with $\lambda_{\text {tis/bl }}=2.5$ and $(b)$ VRG 1 tissues are not assumed to be in equilibrium with local venous concentration; there is no desorption and local venous concentration equals $C_{A r t}$, the volume of the bloodflow in the fast parts equals $V_{\text {Fast }}=1.21$ (table 3).

Using equation 1 , with $Q_{\text {slow }}=3.51 / \mathrm{min}$, the first condition gives a half time of $80 \mathrm{~s}$ whereas the second condition gives $t_{\frac{1}{2}}=14 \mathrm{~s}$. During the first $10-30 \mathrm{~s}$ after stoppage of the uptake, desorption out of the VRG 1 tissues is unlikely to cause a much longer half time than $t_{\frac{1}{2}}=14 \mathrm{~s}$. Probably after some time the first condition starts to dominate. The desorption becomes more important and this may explain the observed change of $t_{\frac{1}{2}}$ from 15 to $25 \mathrm{~s}$ to 20 to $50 \mathrm{~s}$ at about $\mathrm{t}-\mathrm{t}_{1}=20 \mathrm{~s}$.

Respiratory excretion can shorten the half time because of an extra output out of the fast system. This respiratory output is low compared with the output yielded by the bloodflow $\bigotimes_{\text {Slow. }}$.

In the early postexposure period $\mathrm{C}_{\mathrm{Ven}}$ is strongly affected by large differences in $(a)$ partial pressures in the fast perfused organs and tissues and $(b)$ in their corresponding circulation times. This becomes apparent with sampling after $\mathrm{t}^{*}=20 \mathrm{~s}$ which yields a $10 \%$ higher $\mathrm{C}_{\mathrm{Alv}}$ value than $\mathrm{C}_{\mathrm{Alv}}\left(\mathrm{t}^{*}=10 \mathrm{~s}\right)$ (table 1 and fig 1). It seems plausible that a relatively high local venous concentration coming from fast perfused organs, tissues, or shunts reacts on changes in respiratory excretion within 10-20 s and is able to affect the $C_{\text {Ven }}$ value. In the later postexposure period $\left(t-t_{1}\right)>$ 35 min large differences have disappeared and the fast perfused tissues and organs are no longer able to

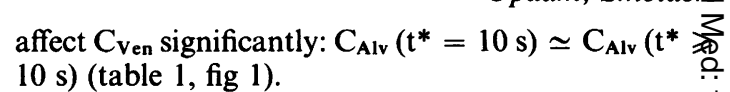

It may be concluded that the decrease of the alve $\overrightarrow{\vec{F}}$ lar concentration at $t_{1}$ is mainly caused by the mixing of local venous blood coming from a rapid VRG 委 compartment and a rapid shunt with local venow blood coming from the slower compartments.

STATIONARY LEVEL AND CAIv COURSE BEYOND ڤ THE LEVEL

In the postexposure period slower, well perfused organs and tissues are responsible for the course beyond the stationary level $\left(t>t_{3}\right)$. A two compars ment model was fitted to the data of $\mathrm{C}_{\mathrm{Alv}}$ beyond the stationary level of an experiment (appendix 2, eq $2 \mathrm{~F}$ The coefficients and exponents $\left(c(1), c(2), r_{1}, r_{2}\right)$ of the fitted function (appendix 2, eq 2) were used to calcu late a course of $C_{A l v}$ during exposure by means of equation 1 (appendix 2); this $C_{A l v}$ course reflects the venous concentration $\mathrm{C}_{\text {Slow }}$ during exposure. Figure $\vec{z}$ shows that the value of the stationary level in differerit experiments equals this calculated venous concent tration. This suggests that the mixture of local cow centrations coming mainly from the slower well per fused organs and tissues can be measured at first the stationary level.

The splanchnic tissue is well perfused $(1.5 \mathrm{l} / \mathrm{min}$ and much more saturated than the muscles and fat i the postexposure period $(0-60 \mathrm{~min})$. Therefore, the contribution from the splanchnic tissue, which includes the liver, to $\mathrm{C}_{\mathrm{Ven}}$ is rather large. It seems plausible that the splanchnic tissue is most responsible for the existence and magnitude of the stationary level and also for the change in $\mathrm{C}_{\mathrm{Ven}}$ in the post level period up to about 60 minutes. This pose exposure period seems to offer the opportunity to study the kinetics of the splanchnic tissue in mose detail. In particular this postexposure period might bo important for assessing individual metabolism in the liver.

In summary, fast kinetic phenomena were studie by means of abrupt stoppage of respiratory intake This was realised by long breath holding during exposure or by breathing fresh air immediately at the end of exposure. During exposure, breath holding. does decrease alveolar concentration considerably. Ati the end of exposure, the subject inhaled fresh air and a similar decrease of alveolar concentration occurres which is scarcely delayed by breath holding. It was concluded that the rapid decrease in the mixed venous concentration causes a rapid decrease in the alveolat concentration. This rapid mixed venous decrease could be explained by the rapid venous blood returning from well perfused small organs, tissues, of shunts with short circulation times (10-20 s). Aftêf exposure, the decrease of alveolar concentration w市 
not smooth but it slowed down abruptly after a few minutes and a short stationary level of one to three minutes occurred. Beyond this level, the decrease was continued at a slower rate. Riley et al found a similar pattern in the rate of alveolar decrease after exposure to methylene chloride but could offer no physiological explanation. ${ }^{10}$ In this paper we suggest that the stationary level was due to mixed venous blood coming from more slowly perfused organs and tissues, in particular the splanchnic tissue. For the assessment of individual metabolism in the liver, the alveolar course beyond the stationary level might be important.

To assess the kinetics of fast phenomena, we suggest that a small compartment or shunt, or both, with a blood circulation time of 10-15 s must be added to the conventional compartment model; the bloodflows which belong to the other compartments have longer circulation times (about 40-55 s).

Alveolar air sampling is non-invasive and allows frequent sampling. As a result we were able to distinguish the stationary level and to assess the fast kinetics of a solvent in the body. This method may provide information on individual differences in fast kinetic data.

This study was supported by the Ministry of Social Affairs and Employment (Project No ASA 528). We thank Professor Dr R L Zielhuis, Dr A C Monster, Mrs A J Bakker, and Mr R van Rijswijk for their helpful participation.

\section{Appendix 1}

SYMBOLS AND ABBREVIATIONS USED IN THE TEXT AND APPENDIX 2

$t^{*}$

Residence time; total time in which gas exchange can take place between inhaled alveolar air and blood in the capillary bed of the lung (s)

$t_{\frac{1}{2}}$ Half time of $\mathrm{C}_{\mathrm{Alv}}$ decrease between $\mathrm{C}_{\mathrm{Alv}}\left(\mathrm{t}^{*}=10 \mathrm{~s}\right)$ at $\mathrm{t}_{1}$ and $\mathrm{C}_{\mathrm{SL}}$ at $\mathrm{t}_{2}(\mathrm{~s})$

$t_{1} \quad$ Point of time at the end of

$\mathrm{t}_{2}$ Point of time at the beginning of exposure (min) the stationary level ( $\mathrm{min}$ )

$t_{3}$

$\mathrm{C}_{\mathrm{I}}$

$\mathrm{C}_{\text {Alv }}$

$\mathrm{C}_{\mathrm{Alv}} / \mathrm{C}_{\mathrm{I}}$ air $(\mu \mathrm{g} / \mathrm{l})$ during exposure air $(\mu \mathrm{g} / \mathrm{l})$

Concentration of PER in alveolar
$\mathrm{C}_{\mathrm{Alv}}\left(\mathrm{t}^{*}=\mathrm{x} \mathrm{s}\right)$

$\mathrm{C}_{\mathrm{Alv}}\left(\mathrm{t}^{*}=10 \mathrm{~s}\right)_{\mathrm{t}_{1}}$

$\mathrm{C}_{\mathrm{Ven}_{\text {en }}}, \mathrm{P}_{\mathrm{Ven}}$

$\mathrm{C}_{\mathrm{Art}}, \mathrm{P}_{\mathrm{Art}}$

$\mathrm{C}_{\mathrm{SL}}$

$\mathrm{C}^{*} \mathrm{sL}$

CSlow

VRG 1 a

VRG $1 \mathrm{~b}$

VRG 1

VRG 2

VRG

MG

FG

Qslow

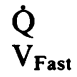

$\lambda$

$\lambda_{\text {tis/bl }}$

\section{Appendix 2}

Compartment models have been used often in pharmokinetics. The number of compartments are often made equal to the number of exponents that are onds $(\mu \mathrm{g} / \mathrm{l})$ $(\mu \mathrm{g} / \mathrm{l})$ returning to the lungs $(\mu \mathrm{g} / \mathrm{l}, \mathrm{Pa})$ the lungs $(\mu \mathrm{g} / \mathrm{l}, \mathrm{Pa})$ $t_{3}(\mu \mathrm{g} / \mathrm{l})$ $(\mu \mathrm{g} / \mathrm{l})$ $(\mu \mathrm{g} / \mathrm{l})$ adrenals thyroid, etc small glands and organs

VRG 1 a + VRG 1 b onds: splanchnic tissue

Vessel rich group compartment:

VRG $1 \mathrm{a}$ + VRG $1 \mathrm{~b}$ + VRG 2

Muscle group compartment

Fat group compartment $(1 / \mathrm{min})$

Cardiac output $(1 / \mathrm{min})$ sponding blood volunme (1)

Blood/air partition coefficient Tissue/blood partition coefficient onds at the end of exposure $t_{1}$

Concentration or partial pressure of PER in mixed venous blood

Concentration or partial pressure of PER in arterial blood leaving

Concentration in alveolar air at the stationary level between $t_{2}$ and

Concentration in mixed venous blood at the stationary level between $t_{2}$ and $t_{3}$-that is $C_{S L} / \lambda$;

Concentration in venous blood coming from VRG2, MG, and FG compartments and slow shunts

Rapidly well perfused organs and tissues with a short transit time of two to three seconds: kidneys,

Rapidly well perfused organs and tissues with a short transit time of 6-11 seconds; heart, brains, and

Well perfused organs and tissues with a transit time of about 40 sec-

Blood flow returning to the lungs coming from VRG2, MG, and FG compartments and slow shunts

Distribution volume of the fast system which is composed by URG1, fast shunt, and a correair relative to the concentration in inhaled air 
necessary to fit the experimental data adequately. During and after exposure the following functions may be fitted to the observed $\mathrm{C}_{\mathbf{A l v}}$ data ${ }^{5}$ :

$$
C_{\text {Ven }} \simeq C_{A l v}(t)=\sum_{i=1}^{p} c(i)\left(1-e^{r i t}\right)
$$

$\mathrm{t} \leqslant \mathrm{t}_{1}$

$$
C_{\text {Ven }} \simeq C_{A l v}(t)=\sum_{i=1}^{p} c(i)\left(e^{r_{1}\left(t-t_{1}\right)}-e^{r_{i t} t}\right)
$$

$t \geqslant t_{1}$

where $t_{1}=$ end of exposure; $p=$ number of compartments; $c(i), r_{i}(=$ neg) with $i=1,2 \ldots, p$ are estimated coefficients and exponents obtained from the fitting.

The weighted residual error of the observed data around the fitted curve equals:

$$
\sqrt{\frac{1}{n-2 p}} \sum_{i=1}^{n}\left(\frac{y_{i}-\hat{y}_{i}}{\hat{y}_{i}}\right)^{2} \times 100 \%
$$

where $y_{i}=$ observed value of a sample point $(i=1$, $2, \ldots n) ; \hat{y}_{i}=$ calculated value by means of the fitted curve with $2 p$ parameters.

\section{References}

1 Fernandez JG, Droz PO, Humbert BE, Caperos JR. Trichloroethylene exposure. Simulation of uptake, excretion, and metabolism using a mathematical model. Br J Ind Med 1977;34:43-55.
2 Mapleson WW. Circulation-time models of the uptake $?$ of inhaled anaesthetics and data for quantifying them. Br J Anaesth 1973;45:319-34.

3 Opdam JJG, Smolders JFJ. Alveolar sampling and fast kinetics of tetrachloroethene in humans I. Alveolar sampling. Br J Ind Med 1986;43:814-24.

4 Sato A, Nakajima T. A structure-activity relationship of $\underset{\mathbb{D}}{ }$ some chlorinated hydrocarbons. Arch Environ Health 1979;34:69-75.

5 Piotrowski I. The application of metabolic and excretion $\overrightarrow{0}$ kinetics to problems of industrial toxicology. Washington: Department of Health, Education and $\vec{\omega}$ Welfare, 1971.

6 Cowles AL, Borgstedt HH, Gillies AJ. Tissue weights $\underset{\mathbb{D}}{\mathscr{D}}$ and rates of blood flow in man for the prediction of 3 anesthetic uptake and distribution. Anesthesiology $\stackrel{+}{\perp}$ 1971;35:523-5.

7 Monster AC, Boersma G, Steenweg H. Kinetics of $\vec{\sim}$ tetrachloroethylene in volunteers; influence of $\infty$ exposure concentrations and workload. Int Arch음 Occup Environ Health 1979;42:303-9.

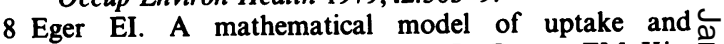
distribution of anesthetic agents. In: Papper EM, Kitz $\mathrm{RJ}$, eds. Uptake and distribution of anesthetic agents New York: McGraw-Hill, 1963:77-103.

9 Steward A, Allott PR, Cowles AL, Mapleson WW. $\overrightarrow{0}$ Solubility coefficients for inhaled anaesthetics for ${ }^{\infty}$ water, oil and biological media. Br J Anaesth 1973;45:282-93.

10 Riley EC, Fasset DW, Sutton WL. Methylene chloride vapor in expired air of human subjects. Am Ind Hyg Assoc $J$ 1966;27:341-8. 